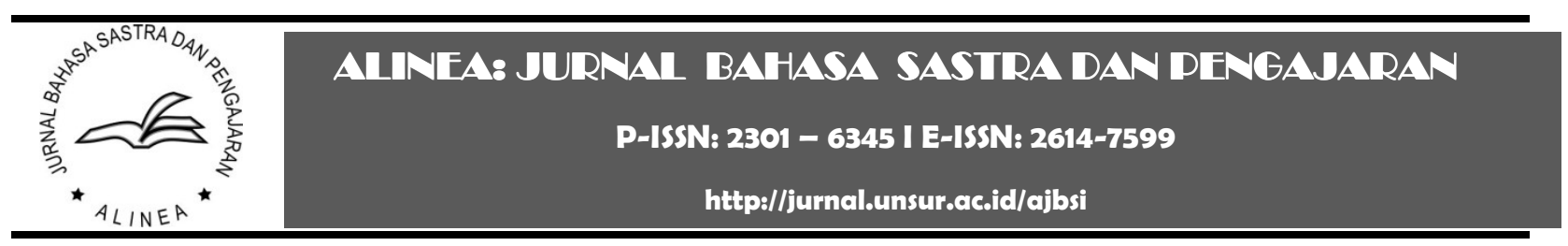

\title{
CITRA PEREMPUAN DALAM NOVEL KALA KARYA STEFANI BELLA DAN SYAHID MUHAMMAD
}

\author{
Hanif Ivo Khusri Wardani \& Rina Ratih \\ Universitas Ahmad Dahlan Yogyakarta, Indonesia
}

Riwayat artikel:

Dikirim: 5 September 2020

Direvisi: 9 September 2020

Diterima: 9 September 2020

Diterbitkan: 30 Oktober 2020

\section{Katakunci:}

citra, perempuan, feminis ideologis

Keywords:

image, women, ideological feminism

Alamat surat

hanifwardhani29@gmail.com

\begin{abstract}
Abstrak:
Penelitian bertujuan untuk mendeskripsikan citra perempuan pada tokoh utama dalam novel "Kala" karya Stefani Bella dan Syahid Muhammad dengan kajian feminisme ideologis. Penelitian dilakukan secara deskriptif kualitatif. Pengumpulan data dilakukan dengan teknik kepustakaan dan teknik baca-catat serta metode membaca sebagai perempuan. Hasil penelitian adalah sebagai berikut: (1) citra fisik Lara adalah perempuan dewasa yang sederhana, apa adanya, dan tidak suka bersolek, (2) citra psikis Lara adalah perempuan yang berjiwa kuat, tegar, tanggung jawab, dan mandiri, (3) citra sosial Lara dalam keluarga adalah anak perempuan yang berbakti kepada orang tuanya, dan (4) citra sosial Lara dalam masyarakat adalah perempuan yang ramah, mudah bergaul, dan aktif berkegiatan. Sosok perempuan dalam novel "Kala" ini menggambarkan sosok perempuan yang berhasil menyetarakan kedudukannya dengan laki-laki khususnya dalam bidang pekerjaan di ranah publik. Ketidakadilan yang dihadapinya karena jenis kelamin tidak menjadikan perempuan lemah dan terpuruk tetapi membangkitkan semangatnya menjadi perempuan yang mandiri.
\end{abstract}

\begin{abstract}
:
The study aimed to describe the woman's image reflected by the main character of Kala, a novel written by Stefani Bella and Syahid Muhammad. The woman's image was viewed from an ideological feminism approach. The research was descriptive qualitative of which the data were collected through library study and note-taking, as well as reading as woman. The study results in several findings. First, Lara's physical image was described as modest, natural, and not keen on prinking herself. Second, psychologically, Lara's image was strong, tough, responsible, and independent. Third, Lara's social image in the family was filial to her parents, and fourth, Lara's social image in society was described as friendly, sociable, and active. The woman's figure in the novel shows the one who is able to equalize the position with men, especially in occupations related to the people. The inequality as experienced by the character should not weaken women. Instead, it should encourage women to be independent.
\end{abstract}

\section{PENDAHULUAN}

Penggambaran tokoh perempuan dalam karya sastra sering berbanding terbalik dengan tokoh laki-laki. Laki-laki digambarkan sebagai sosok yang gagah, kuat, dan perkasa, sedangkan perempuan digambarkan sebagai sosok yang lemah, lembut, dan mudah menyerah. Perempuan adalah anggota masyarakat dengan berbagai aktivitas sosialnya yang terefleksi dalam produk budaya. Perempuan memiliki persoalan dan pengalaman hidup yang berbeda dengan laki-laki dalam masyarakat patriarkhat (Ratih, 2019).

Salah satu masalah yang dialami perempuan di Indonesia adalah menikah usia dini. Menurut Council of Foreign Relations, Indonesia merupakan salah satu dari sepuluh negara di dunia dengan angka absolut tertinggi pengantin anak. Indonesia adalah yang tertinggi kedua di ASEAN setelah Kamboja. 
Diperkirakan satu dari lima anak perempuan di Indonesia menikah sebelum mereka mencapai 18 tahun (Candraningrum, 2016).

Masalah yang dihadapi perempuan di masyarakat diekspresikan oleh pengarang melalui karya sastra sehingga seringkali ditampilkan tokoh-tokoh perempuan dengan segala permasalahan hidup dan bagaimana perempuan itu menghadapi masalahnya sampai akhirnya6ditemukan citra seorang perempuan. Gambaran atau citra perempuan ini menarik diteliti karena tidak hanya digambarkan oleh pengarang di dalam karya sastra tetapi juga menjadi stereotipe perempuan di masyarakat. Tokoh perempuan dalam karya sastra sering kali digambarkan sebagai tokoh yang mengalami ketidakadilan. Akan tetapi, tidak sedikit tokoh perempuan memiliki kesadaran untuk mendapatkan kesetaraan gender, sebagaimana tokoh perempuan dalam novel Kala karya Stefani Bella dan Sayid Muhammad.

Kajian yang khusus membahas mengenai perempuan dikenal dengan kajian feminisme. Menurut Djajanegara (2000: 16-17) kajian perempuan mencakup berbagai topik yang bertalian dengan perempuan, seperti sejarah perempuan, buruh perempuan, psikologi perempuan, lesbianisme, dan lain-lain. Pada dasarnya feminisme adalah gerakan untuk menuntut kesetaraan gender. Tujuannya yaitu agar perempuan dipandang setara dengan lakilaki sehingga kaum perempuan tidak akan dipandang sebagai kaum yang lemah lagi. Selain itu dengan adanya kesetaraan gender membuat perempuan tidak lagi merasakan ketertindasan dari kaum laki-laki. Inti tujuan feminisme adalah meningkatkan kedudukan dan derajat perempuan agar sama atau sejajar dengan kedudukan serta derajat laki-laki. Meskipun perempuan diidentifikasikan dengan kelas proletar atau kelas yang tertindas, dan kaum laki-laki disamakan dengan kelas borjuis atau kelas penindas, gerakan perempuan pada umumnya tidak bermaksud membalas dendam dengan menindas atau menguasai laki-laki.
Kritik sastra feminisme digunakan oleh para feminis untuk mengkaji dan menunjukkan citra perempuan dalam suatu karya sastra. Citra tersebut timbul karena adanya konsep gender, yaitu suatu sifat yang melekat pada diri perempuan. Adapun yang dimaksud 'citra perempuan' merupakan wujud gambaran mental spiritual dan tingkah laku keseharian yang terekspresi oleh perempuan dalam berbagai aspeknya yaitu aspek fisis dan psikis sebagai citra diri perempuan serta aspek keluarga dan masyarakat sebagai citra sosial. Kata citra perempuan diambil dari gambarangambaran citraan, yang ditimbulkan oleh pikiran, pendengaran, penglihatan, perabaan, dan pencecapan tentang perempuan (Sugihastuti, 2000: 45).

Lahirnya kritik sastra feminis tidak dapat dipisahkan dari gerakan feminisme yang pada awalnya muncul di Amerika Serikat pada tahun 1700-an (Madsen, 2000: 1). Menurut Humm (2007: 157-158) feminisme menggabungkan doktrin persamaan hak bagi perempuan yang menjadi gerakan yang terorganisasi untuk mencapai hak asasi perempuan, dengan sebuah ideologi transformasi sosial yang bertujuan untuk menciptakan dunia bagi perempuan. Selanjutnya Humm (2007:157-158) menyatakan bahwa feminisme merupakan ideologi pembebasan perempuan dengan keyakinan bahwa perempuan mengalami ketidakadilan karena jenis kelaminnya.

Feminisme menawarkan berbagai analisis mengenai penyebab dan pelaku dari penindasan perempuan. Dalam buku berjudul Feminist Thought, Rosemarie Putnam Tong (2006) mengemukakan bahwa feminisme bukanlah sebuah pemikiran yang tunggal, melainkan memiliki berbagai ragam yang kemunculan dan perkembangannya sering kali saling mendukung, mengoreksi, dan menyangkal pemikiran feminisme sebelumnya.

Dalam perkembangannya ada beberapa ragam kritik sastra feminis. Showalter (1986) membedakan adanya dua jenis kritik sastra feminis, yaitu: (1) kritik sastra feminis yang 
melihat perempuan sebagai pembaca (the woman as reader/feminist cri que), dan (2) kritik sastra feminis yang melihat perempuan sebagai penulis (the woman as writer/g ynocri $c s)$. Kritik sastra feminis aliran perempuan sebagai pembaca (woman as reader) memfokuskan kajian pada citra dan stereotip perempuan dalam sastra, pengabaian dan kesalahpahaman tentang perempuan dalam kritik sebelumnya, dan celah-celah dalam sejarah sastra yang dibentuk oleh laki-laki (Showalter dalam Wiyatmi, 2010: 30).

Kritik ragam ideologis ini dengan sendirinya berbeda sekali dari male critical theory atau teori kritik laki-laki yang merupakan suatu konsep kreativitas, sejarah sastra, dan penafsiran sastra yang seluruhnya didasarkan pada pengalaman laki-laki dan yang disodorkan sebagai suatu teori semesta yang berlaku secara universal (Djajanegara, 2000: 29).

Penelitian yang menggunakan kajian feminisme telah dilakukan oleh para peneliti sebelumnya. Penelitian tentang citra perempuan telah dilakukan oleh Putri Haryanti berjudul "Citra Perempuan dalam Lirik Lagu 'Bojo Galak' Karya Pendhoza” (2018) dan Syska Istanti berjudul "Citra Perempuan dalam Novel Cinta Suci Zahrana Karya Habiburrahman El Shirazy: Tinjauan Kritik Sastra Feminis” (2018). Penelitian Haryanti memiliki kesamaan dengan penelitian ini karena membahas citra perempuan sebagai objeknya dan sama sama menggunakan teori feminis. Perbedaannya terletak pada subjek penelitian, Haryanti menggunakan genre lirik lagu sedangkan penelitian ini menggunakan novel. Penelitian yang dilakukan Istanti memiliki persamaan dengan penelitian ini khususnya objek, subjek, dan teori, yaitu citra perempuan, novel, dan teori feminis. Perbedaannya terletak pada pilihan novel. Istanti mengunakan novel Cinta Suci Zahrana karya Habiburrahman El Shirazy, sedangkan penelitian ini menggunakan novel Kala karya Stefani Bella dan Sayid Muhammad.
Penelitian terhadap citra perempuan dalam novel-novel Indonesia tahun 1920-2000 telah dilakukan Didi Suhendi. Hasil penelitiannya mengemukakan bahwa citra perempuan dalam novel-novel Indonesia mengalami pergeseran dari perempuan domestik ke perempuan publik. Akan tetapi, mayoritas perempuan dalam novel-novel Indonesia tahun 1920-2000 menghendaki dirinya sebagai perempuan domestik yang perannya mengurus rumah tangga dan melayani kepentingan laki-laki (suaminya). Citra perempuan yang demikian muncul, baik pada novel-novel karya pengarang perempuan maupun karya pengarang laki-laki, sebagaimana dijelaskan Suhendi dalam disertasinya berjudul "Perempuan dalam Novel- Novel Indonesia 1920-2000: Kajian Kritik Sastra Feminis Islam" (2010).

Penelitian terhadap citra perempuan Jawa dalam novel Sinden Karya Dwi RahayuNingsih: Kajian Feminisme Liberal telah dilakukan oleh Nur Fitriani (2019). Hasil penelitiannya menjelaskan bahwa citra perempuan dalam novel Sinden memiliki sifat nrimo, sabar, pasrah, lembut, bakti, dan pandai berhemat, memiliki perhatian kepada orang lain dan pengendalian diri tinggi. Perbedaan penelitian Nur Fitriani dengan penelitian ini terletak pada subjeknya saja sedangkan objek dan teorinya sama yaitu citra perempuan dengan teori feminis.

Berdasarkan penjelasan di atas, penelitian yang membahas citra perempuan dalam novel Kala belum dilakukan. Pada umumnya penelitian-penelitian yang membahas citra perempuan menggunakan teori teminis. Akan tetapi, masalah yang dihadapi tokoh berbeda sehingga hasil penelitiannya pun berbeda. Mindset yang ada dalam diri tokoh mempengaruhi bagaimana perempuan bersikap. Kesadaran perempuan terhadap dirinya yang feminim dan sekaligus kesadaran untuk dapat setara dengan laki-laki sudah muncul sehingga dengan berbagai upaya mencoba menempatkan dirinya sejajar dalam berbagai aspek kehidupan, sebagaimana dialami tokoh perempuan dalam novel Kala. 
Novel Kala ini menarik untuk diteliti karena tokoh utama menghadapi berbagai permasalahan hidup sebagai perempuan di tengah kekuasaan budaya patriakhi dan berusaha mematahkan citra perempuan yang lemah, tidak berpendidikan, dan tidak mandiri.

Penelitian bertujuan untuk mendeskripsikan citra perempuan dalam novel Kala karya Stefani Bella dan Syahid Muhammad. Penelitian menggunakan kajian kritik sastra feminis ideologis karena kritik inilah yang mengarah pada studi sastra yang memokuskan diri pada analisis tentang perempuan. Kritik ini mempersoalkan asumsi-asumsi tentang perempuan berdasarkan paham tertentu yang dikaitkan dengan kodrat perempuan. Kritik ini juga berusaha mengidentifikasi pengalaman dan perspektif pemikiran perempuan dan lakilaki yang direpresentasikan dalam teks sastra.

Kritik sastra feminis mencakup (1) penelitian terhadap perempuan, yaitu bagaimana laki-laki memandang perempuan dan bagaimana perempuan dilukiskan dalam teks sastra, (2) penelitian tentang perempuan, yaitu tentang kreativitas perempuan yang terkait dengan potensi perempuan di tengah-tengah tradisi masyarakat patriarki, dan (3) penelitian yang berkaitan dengan penggunaan teori dalam kajian tentang perempuan (Ruthven, 1984:24-58). Dengan kata lain, kritik sastra feminis ini meliputi penelitian tentang bagaimana perempuan dilukiskan dalam karya sastra dan bagaimana potensi yang dimiliki perempuan di tengah kekuasaan patriarki (Ruthven, 1984:40-50).

Kritikus feminis meneliti bagaimana kaum perempuan ditampilkan, bagaimana suatu teks membahas relasi jender dan perbedaan jenis kelamin. Dari perspektif feminis, sastra tidak boleh diisolasi dari konteks atau kebudayaan di mana sastra merupakan salah satu bagiannya. Kritik sastra feminis menunjukkan bahwa pembaca dan kritikus perempuan telah menciptakan persepsi dan harapan yang berbeda terhadap pengalaman sastranya (Showalter, 1985:3).
Kritik sastra feminis senantiasa menginginkan adanya relasi gender yang setara. Kritik ini mengkaji masalah yang berkaitan dengan posisi kaum perempuan dalam ranah domestik dan publik dalam relasinya dengan kaum laki-laki. Masalah keberadaan perempuan dalam puisi dapat dipahami dalam persfektif feminis. Sebagaimana dikemukakan Reinhartz (2005:221) bahwa penelitian feminis memiliki tujuan untuk mengidentifikasi penghilangan, penghapusan, dan informasi yang hilang tentang perempuan secara umum. Selanjutnya Reinhartz menegaskan bahwa memahami perempuan dari perspektif feminis adalah memahami pengalaman dari sudut pandang perempuan sendiri yang dapat memperbaiki ketimpangan utama cara pandang non feminis yang meremehkan aktivitas dan pemikiran perempuan atau menafsirkannya dari sudut pandang laki-laki di masyarakat. Melalui kajian feminis diharapkan dapat mengungkapkan kekuatan budaya patriarkat yang membentuk citra mengenai perempuan dan laki-laki, relasi antara keduanya, atau adanya perlawanan terhadap dominasi patriarkat yang terefleksi dalam karya sastra.

\section{METODE}

Penelitian dilakukan secara deskriptif kualitatif. Subjek penelitian adalah novel Kala karya Stefani Bella dan Syahid Muhammad (Gradien Mediatama, 2017). Objek yang digunakan dalam penelitian adalah manusia, baik secara material maupun formal (Siswantoro, 2005:54). Objek formal penelitian adalah citra perempuan, meliputi citra fisik, psikis, dan sosial.

Teknik pengumpulan data dalam penelitian menggunakan teknik kepustakaan dan teknik baca-catat serta menggunakan metode membaca sebagai perempuan atau reading as a woman. Yang dimaksud "membaca sebagai perempuan" adalah kesadaran pembaca bahwa ada perbedaan penting dalam jenis kelamin pada makna dan perebutan makna karya sastra (Sugihastuti, 2016: 7). Menurut Culler bahwa prinsip reading as a woman dikenal sebagai prinsip 
yang sekiranya pantas dipakai untuk membongkar praduga dan ideologi kekuasaan laki-laki yang androsentris atau patriarkhat, yang sampai sekarang diasumsikan menguasai penulisan dan pembacaan sastra.

Kritik sastra feminis yang diartikan membaca sebagai perempuan berpandangan bahwa kritik ini tidak mencari metodologi atau model konseptual tunggal, tetapi bahkan sebaliknya menjadi pluralis dalam teori dan praktiknya, menggunakan kebebasan dalam metodologi dan pendekatan yang dapat membantu pelaksanaan kritiknya (Sugihastuti, 2016: 10)

\section{HASIL PENELITIAN}

\section{Citra Diri Perempuan dalam Aspek Fisik}

Citra diri perempuan dalam aspek fisik yang digambarkan dalam novel ini adalah seorang tokoh perempuan dewasa, ditandai dengan berbagai perubahan dalam dirinya, sebagaimana tampak pada kutipan berikut.

Tepat pada usiaku telah resmi berubah menjadi dua puluh lima, aku terbangun dengan mata sebesar bola pingpong sebagai akibat menangis semalam suntuk (Kala, 2017: 20).

Aku seharusnya telah lihai memoleskan lipstik di bibir, sudah pandai mengenakan sepatu berjinjit ... Memoleskan bedak di wajah saja aku sering kali risih. Aku lebih nyaman dengan sepatu kets butut (Kala, 2017: 20).

Berdasarkan kutipan di atas, tokoh utama novel ini bernama Lara, seorang perempuan dewasa berusia 25 tahun. Ia tampil sederhana, tidak suka bersolek. Ia lebih nyaman tidak bermake up. Sehari-hari memilih bersepatu kets daripada sepatu berhak tinggi. Akan tetapi kerasnya perjalanan hidup yang dihadapi Lara sejak kecil membuatnya sering kali terbangun dengan mata bengkak karena menangis semalaman. Mengalami banyak penderitaan sejak kecil membuatnya lebih sabar menahan diri di hadapan ibunya, tetapi sering diam diam menangis sendirian.

\section{Citra Diri Perempuan dalam Aspek Psikis}

Tokoh Lara ditinjau dari aspek psikisnya, digambarkan sebagai perempuan yang berjiwa kuat dan tegar. Perceraian kedua orang tuanya terjadi ketika Lara berusia 5 tahun. Dia tidak pernah berkecil hati meski dibesarkan dari keluarga broken home. Dia tetap tegar dan tumbuh sehat bersama Ibunya. Bagi Lara, perceraian orang tuanya tidak membuatnya kekurangan mendapatkan kasih sayang karena ada ibu yang menyayangi dan mencintainya. Justru Lara merasa memiliki kewajiban melindungi ibunya yang semakin tua. Hal itu didukung dengan kutipan novel di bawah ini.

Sejak umurku tidak kurang dari lima tahun, aku dipaksa menjadi kuat menghadapi perpisahan pertamaku. Saat kedua orang tuaku memilih berpisah (Kala, 2017: 18).

Meski tumbuh tanpa cinta pertama, tanpa seorang Ayah yang katanya menjadi pelindung nomor satu, aku sama sekali tidak pernah menyesalinya. Karena tumbuh dan besar hanya dengan kasih sayang seorang Ibu, ternyata tak membuatku kekurangan apa pun (Kala, 2017: 18-19).

Karena, nyatanya aku yang harus siap jadi pelindung buat Ibuku. Aku yang harus bisa kuat di depan Ibuku (Kala, 2017: 199).

Selain memiliki jiwa yang kuat dan tegar, Lara adalah perempuan yang mandiri. Kemandirian Lara tumbuh saat memasuki usia remaja (SMP) saat kondisi ekonomi keluarganya terpuruk. Ia pun bekerja menjadi tulang punggung keluarga, sebagaimana tampak pada kutipan novel berikut.

Aku baru mengetahui hal itu dari Ibuku saat aku SMP. Saat aku dan Ibuku sedang dalam masa terpuruk. Saat aku secara tidak langsung tengah dilimpahi tugas 
untuk menjadi tulang punggung keluarga (Kala, 2017: 198).

Kemandirian yang dimiliki Lara sejak remaja membentuknya menjadi pribadi yang penuh tanggung jawab. Dia bertanggung jawab atas pekerjaan-pekerjaan yang dibebankan kepadanya. Sampai dewasa, Lara tumbuh menjadi pribadi yang memiliki dedikasi penuh pada pekerjaan yang menjadi tanggung jawabnya. Sampai akhirnya, Lara berhasil bekerja menjadi editor selama 3 tahun di Kota Jakarta dan kemudian dipromosikan menjadi redaktur pelaksana sebuah perusahaan penerbitan di Kota Yogyakarta. Meskipun sudah menjadi redaktur pelaksana, Lara tetap hidup sederhana, mandiri, dan penuh semangat.

Ya, setelah tiga tahun menjadi editor di Jakarta, kali ini aku dipromosikan menjadi redaktur pelaksana di salah satu cabang grup penerbitanku yang berada di wilayah Jogja (Kala, 2017: 163).

Pagi-pagi sekali aku sudah memesan ojek online untuk mengantarku pada acara launching buku yang diadakan di salah satu toko buku di sebuah mal besar di Jogja (Kala, 2017: 273).

Lara adalah perempuan yang cerdas. Ia selalu menyempatkan waktu untuk menuangkan pikiran-pikirannya dalam bentuk tulisan di buku catatannya. Bahkan ia mampu menyampaikan pesan-pesan yang tersirat melalui bahasa tulis hanya dengan melihat objeknya saja. Lara membuktikan dirinya mampu melakukan pekerjaan, baik sebagai editor dan redaktur pelaksana dengan baik. Padahal kedua pekerjaan itu umumnya lebih banyak dilakukan oleh laki-laki.

Sebagai perempuan, Lara pun memiliki perasaan yang bergejolak dalam hatinya saat jatuh cinta dengan seorang laki-laki bernama Saka.

Aku bersumpah, ada gelombang tak biasa yang menggedor-gedor relung hatiku saat mata ini bertemu dengan manik matanya (Kala, 2017: 60).

Selain itu, Lara digambarkan sebagai seorang muslim yang taat dan rajin beribadah. Selain menjalankan salat lima waktu, Lara pun sering salat malam (tahajud) untuk lebih mendekatkan diri kepada sang Pencipta. Hal tersebut didukung dengan kutipan novel berikut ini.

Pada sepertiga malam yang tak pernah ramai, di tengah kekhusyukan dalam beribadah, aku lebih sering dihabisi akal sehatku sendiri (Kala, 2017: 29).

Dari kutipan-kutipan di atas, citra Lara sebagai perempuan ditinjau dari aspek psikis digambarkan sebagai perempuan yang berjiwa kuat, tegar, mandiri, bertanggung jawab, dan religius. Tokoh perempuan ini secara perlahan tetapi menunjukkan dirinya sebagai pribadi yang mampu setara dengan laki-laki, khususnya dalam melakukan pekerjaan sebagai editor dan redaktur pelaksana. Sebagai editor selama tiga tahun di ibu kota bagi tokoh perempuan bukanlah pekerjaan mudah, melainkan pekerjaan yang penuh tantangan. Sebagai redaktur pelaksana, Lara telah membuktikan dirinya bekerja keras dan bertanggung jawab dalam bidang pekerjaan yang biasanya dilakukan oleh laki-laki dewasa. Dua pekerjaan ini membentuk Lara menjadi perempuan yang mandiri dan memberi gambaran bahwa perempuan itu cerdas karena menggunakan akal sehatnya untuk berpikir.

\section{Citra Sosial Perempuan dalam Keluarga}

Lara adalah anak yang berasal dari keluarga broken home tidaklah membuat Lara menjadi anak yang putus asa dan rendah diri. Lara adalah sosok anak perempuan yang menghargai keputusan ibunya bercerai dengan ayahnya dan ia sangat berbakti kepada Ibu yang membesarkannya sejak kecil. Oleh karena itu, dalam kehidupan sehari-harinya, Lara menempatkan posisi ibunya di atas kepentingan dirinya. Ia pun selalu meminta izin kepada Ibunya setiap akan bepergian ke 
mana pun dan segera datang jika ibu memanggilnya pulang. Hal ini didukung dengan kutipan novel berikut ini.

Tiga hari menjelang waktu pameran pun tiba, restu dari Ibu sudah berhasil $\mathrm{ku}$ kantongi (Kala, 2017: 39).

Malam menjelang, aku buru-buru pamit dengan kawan-kawanku sebab Ibuku sudah berulang-ulang menanyakan kapan aku akan pulang (Kala, 2017: 41-42).

Dua kutipan di atas menggambarkan citra Lara sebagai anak perempuan yang berbakti dan menyayangi ibunya. Meskipun sudah sukses bekerja menjadi editor di ibu kota, bahkan menjadi redaktur pelaksana, Lara tetap rendah hati dan menunjukkan diriny sebagai anak perempuan yang baik kepada orang tuanya.

\section{Citra Sosial Perempuan dalam Masyarakat}

Sebagai anggota masyarakat, Lara dikenal sebagai sosok perempuan yang ramah dan mudah bergaul dengan siapa pun. Hal ini dibuktikan saat Lara baru mengikuti komunitas menulis, dia pun mudah beradaptasi dengan teman-temannya. Tidak hanya terjadi saat bekerja di Jakarta tetapi juga terjadi saat bekerja di Yogyakarta. Lara selalu menyapa orang lain sebelum disapa.

Aku menyalami mereka satu per satu ... Tidak perlu waktu lama, aku sudah berhasil masuk dalam percakapanpercakapan yang mereka bangun. (Kala, 2017: 40-41).

Aku mulai menyapa teman-temanku yang ternyata sudah mulai bertukar nama dengan beberapa anggota komunitas fotografi. (Kala, 2017: 51).

Bertemu dengan mereka tak ubahnya membuatku kembali terlibat dalam dialog-dialog yang melenakan. Dialog yang berhasil mengubah hari yang semula hanya berwarna hitam dan putih, kini sedikit demi sedikit memiliki warnanya. (Kala, 2017: 37).
Dalam masyarakat pun Lara memiliki peran sebagai perempuan yang aktif mengikuti komunitas. Komunitas yang diikuti Lara adalah komunitas menulis. Lara pertama kali mengikuti komunitas menulis pada saat dia masih menetap di Jakarta. Kepindahannya ke Yogyakarta tidak membuat Lara untuk berhenti menjadi seorang penulis. Lara justru bergabung dengan komunitas menulis yang ada di kota Yogyakarta. Hal itu didukung kutipan novel berikut.

Semenjak satu tahun lalu, aku akhirnya memutuskan untuk ikut sebuah komunitas menulis. Komunitas yang akhirnya memberikan kesempatan kepadaku untuk bertemu dengan orang-orang baru (Kala, 2017: 36).

Sejak kepindahanku ke Jogja, aku memang kembali mencari komunitas yang sama seperti dulu waktu di Jakarta (Kala, 2017: 248).

Dua kutipan di atas menunjukkan bahwa Lara adalah perempuan yang aktif bersosialisasi, khususnya dalam komunitas menulis. Lara, tidak hanya mudah bergaul, tetapi juga sosok perempuan yang tidak membedabedakan teman. Ia dapat bercakap dengan teman sejenis atau lawan jenisnya. Ia pun tidak memandang seseorang dari mana asalnya, sukunya, atau agamanya untuk diajak berbicara dengannya. Ia menunjukkan dirinya supel bergaul.

Aku bisa ditemukan asyik bercakap dengan banyak orang, bergaul dengan siapa saja tanpa pernah mempermasalahkan suku, agama, ras, strata sosial, atau gender yang sering diributkan di negeri ini (Kala, 2017: 20).

Dari penjelasan di atas dapat disimpulkan bahwa citra sosial perempuan dalam masyarakat berupa hubungannya dengan orang per orang di masyarakat umum ditunjukkan Lara sebagai perempuan yang ramah, mudah bergaul, dan aktif dalam kegiatan di masyarakat. 
Berdasarkan penjelasan di atas, tokoh perempuan Lara dalam novel Kala ditinjau dari citra diri dari aspek fisik, psikis, dan sosial, berhasil menggambarkan diri sebagai perempuan yang telah mencapai kesetaraan gender, khususnya dalam pekerjaan di ranah publik. Hal ini sejalan dengan konsep feminis, karena pada dasarnya feminisme adalah gerakan untuk menuntut kesetaraan gender. Tujuannya yaitu agar perempuan dipandang setara dengan laki-laki sehingga kaum perempuan tidak akan dipandang sebagai kaum yang lemah lagi. Kemandirian Lara saat dewasa tidak lepas dari kemauan kerasnya untuk bekerja membantu ibunya dan menjadi tulang punggung keluarga sejak remaja. Kemandirian dan tanggung jawab pekerjaan yang dilakukannya sejak remaja itulah yang membentuk kepribadian Lara menjadi perempuan yang mandiri. Ia bukan perempuan lemah dan mudah berputus asa. Ia memiliki kesadaran meskipun dirinya perempuan, namun mampu bekerja seperti halnya lakilaki. Kekuatan lainnya yang dimiliki Lara adalah percaya kepada Tuhan yang telah memberinya cobaan hidup. Ia selalu memasrahkan dirinya hanya kepada Allah sehingga kesulitan hidup dihadapinya dengan akal sehat bukan dengan putus asa dan pasrah pada keadaaan.

Perempuan pada novel Kala ini sesungguhnya telah memenuhi tujuan kaum feminis karena inti tujuan feminisme adalah meningkatkan kedudukan dan derajat perempuan agar sama atau sejajar dengan kedudukan serta derajat laki-laki. Pekerjaannya sebagai editor dan redaktur pelaksana biasanya merupakan 'pekerjaan laki-laki' karena pekerjaan ini menuntut kecerdasan dan keterampilan berpikir serta tanggung jawab. Lara, perempuan dalam novel ini telah berhasil menunjukkan dirinya mendapatkan pekerjaan itu. Artinya, sebagai perempuan, ia telah mampu mengerjakan pekerjaan yang umumnya dilakukan oleh laki-laki. Ia menunjukkan dirinya layak mendapat pekerjaan itu. Ia bekerja penuh semangat dan tanggung jawab. Pekerjaan sebagai editor dan redaktur pelaksana tidak hanya cocok dilakukan oleh laki-laki tetapi dapat juga dilakukan oleh seorang perempuan. Dengan demikian, perempuan diberi kepercayaan penuh sebagaimana kepercayaan kepada lakilaki. Sesungguhnya, ketika seorang perempuan diberi kesempatan, ia akan menunjukkan dirinya mampu. Apalagi jika perempuan tersebut berpendidikan sehingga tidak menghadapi ketidakadilan yang disebabkan oleh jenis kelamin.

\section{SIMPULAN}

Citra perempuan dalam novel Kala karya Stefani Bella dan Syahid Muhammad adalah sebagai berikut: (1) citra fisik Lara adalah perempuan dewasa yang sederhana, apa adanya, dan tidak suka bersolek, (2) citra psikis Lara adalah perempuan yang berjiwa kuat, tegar, tanggung jawab, dan mandiri, (3) citra sosial Lara dalam keluarga adalah anak perempuan yang berbakti kepada orang tuanya, dan (4) citra sosial Lara dalam masyarakat adalah perempuan yang ramah, mudah bergaul, dan aktif berkegiatan. Sosok perempuan dalam novel Kala ini menggambarkan sosok perempuan yang berhasil menyetarakan kedudukannya dengan laki-laki khususnya dalam bidang pekerjaan di ranah publik. Ketidakadilan yang dihadapinya karena jenis kelamin tidak menjadikan perempuan lemah dan terpuruk tetapi membangkitkan semangatnya menjadi perempuan yang berjiwa kuat, tegar, religius, dan mandiri.

\section{DAFTAR PUSTAKA}

Bella, Stefani dan Syahid Muhammad. 2019. Kala. Yogyakarta: Gradien Mediatama. 
Candraningrum, Dewi. 2016. “Pernikahan Anak: Status Anak Perempuan?” dalam Jurnal Perempuan Nomor 1, Februari 2016.

Djajanegara, Soenarjati. 2000. Kritik Sastra Feminis. Jakarta: Gramedia Pustaka Utama.

Fitriani, Nur. 2019. “Citra Perempuan Jawa dalam Novel Hati Sinden karya Dwi Rahayuningsih: Kajian Feminisme Liberal” dalam Jurnal Sastra Indonesia. Volume 7 No. 1 (2019).

Haryanti, Putri, dkk. 2018. "Citra Perempuan dalam Lirik Lagu Bojo Galak Karya Pendhoza”. Jurnal. Yogyakarta: Universitas Ahmad Dahlan. Diakses melalui http://journal.uad.ac.id/index.php/BAHASTRA/article/view/11441/6213.

Humm, Maggie. 1986. Feminist Criticism. Great Britain: The Harvester Press. . 2007. Ensiklopedia Feminisme. Edisi Bahasa Indonesia diterjemahkan oleh Mundi Rahayu. Yogyakarta: Fajar Pustaka Baru.

1992. Feminisms: A Reader. New York, London, Toronto, Sydney, Tokyo, Singapura: Harvester Whearsheaf.

Istanti, Syska. 2012. "Citra Perempuan dalam Novel Cinta Suci Zahrana Karya Habiburrahman El Shirazy: Tinjauan Kritik Sastra Feminis”. Skripsi. Surakarta: Universitas Muhammadiyah Surakarta. Diakses melalui http://eprints.ums.ac.id/19567/21/NASKAH_PUBLIKASI.pdf.

Madsen. Deborah L. 2000. Feminist Theory and Literary Prac ce. London, Sterling, Virginia: Pluto Press.

Ratih, Rina. 2019. "Dinamika Keberadaan Perempuan dalam Puisi-Puisi Indonesia Pasca Orde Baru: Kajian Feminisme Eksistensialisme Simone de Beauvoir" dalam Bahtera: Jurnal Pendidikan Bahasa, Sasrtra, dan Budaya. Jilid 06/ Nomor 11/ Maret 2019.

Ruthven, K.K. 1984. Feminist Literary Studies an Introduction. Cambridge University Press, Cambridge, New York, Port Chester, Melbourne, Sidney.

Siswantoro. 2005. Penelitian Sastra Analisis Psikologis: Surakarta: Muhammadiyah University Press.

Showalter, Elaine. Ed. 1985. The New Feminist Criticism: Essays on Women, Literature, and Theory. New York: Pantheon.

Suhendi, Didi. 2010. "Perempuan dalam Novel-Novel Indonesia 1920-2000: Kajian Kritik Sastra Feminis Islam”, Disertasi UGM, 2010.

Sugihastuti dan Itsna Hadi Setiawan. 2010. Gender dan Inferioritas Perempuan: Praktik Kritik Sastra Feminis. Yogyakarta: Pustaka Pelajar.

Tong, Rosemary Putnam. 2006. Feminist Thought: A More Comprehensive Introduc on. Diterjemahkan dalam Bahasa Indonesia oleh Aquaini Priyatna Prabasmara. Bandung: Jalasutra.

Wiyatmi. 2010. Kritik Sastra Feminis: Teori dan Aplikasinya dalam sastra Indonesia. Yogyakarta: Ombak. 